\title{
Chronic Kidney Disease and associated factors among HIV/AIDS Patients on HAART at University of Gondar Referral Hospital, Northwest Ethiopia
}

Gizachew Ayele Manaye ( $\square$ ayele.gizachew@yahoo.com )

Mizan-Tepi University

Dejene Derseh Abateneh

Wondwossen Niguse Asmare

Research

Keywords: Chronic Kidney Disease, HIV/AIDS, HARRT, Ethiopia

Posted Date: May 15th, 2020

DOI: https://doi.org/10.21203/rs.3.rs-27467/v1

License: (c) (i) This work is licensed under a Creative Commons Attribution 4.0 International License.

Read Full License 


\section{Abstract \\ Background}

In developing countries, both opportunistic infections and chronic diseases account a high HIV associated mortality and morbidity. Chronic kidney diseases (CKD) associated with HIV infection has got increased attention in sub-Saharan Africa as a result of the high HIV prevalence and due to the late diagnosis and initiation of HAART. Thus, this study was conducted to assess CKD and associated factors among HIV patients on HARRT in Northwest Ethiopia.

\section{Methods}

A hospital-based cross-sectional study with a secondary data review was conducted from February 01 to April 30, 2017, at the University of Gondar Referral Hospital, Northwest Ethiopia. The study participants were selected using a systematic random sampling technique. Socio-demographic and clinical data were collected using a semi-structured questionnaire by trained nurses. Venous blood and urine specimen was collected for serum creatinine and urine protein determination respectively. Glomerular filtration rate was estimated using the CKD-EPI estimator. Data were entered into SPSS version 20 for analysis. Bivariate and multivariate logistic regression was employed and $p$-value $<0.05$ was considered statistically significant.

\section{Results}

A total of 336 HIV patients on HARRT participated in the study. The mean (SD) age of the participants was 39.7 ( \pm 9.7$)$ years. The study participants were on HAART with an average of $7.5( \pm 3)$ years. Before ART initiation, the majority of patients had WHO clinical stage II and III, 251 (74.7\%), CD4 + T cell count < 200 cells $/ \mathrm{mm}^{3}, 221$ (65.8\%). The overall prevalence of CKD was $16.1 \%$. About $27(8.0 \%), 16(4.8 \%), 11$ (3.3\%) of the participants had stage 1 and stage 2 CKD and chronic renal failure (stage 3a-5) respectively. With multivariate logistic regression analysis being male (AOR $=2.05$ (1.03-4.09), $p=0.04$, occupation

merchant $(A O R=2.91(1.00-8.48), p=0.049)$ and viral load $\geq 1000$ copies $/ \mathrm{mm}^{3}(A O R=3.1(1.38-7.00), P<$ 0.01 ) were significantly associated with CKD.

\section{Conclusions}

The prevalence of CKD among HIV patients on HARRT is high. Being male, merchant and viral load $\geq$ 1000 copies $/ \mathrm{mm}^{3}$ were associated factors of CKD. Patients should be regularly monitored and screened for early diagnosis and management of CKD. Those patients with high viral load and male patients should be closely followed. 


\section{Background}

Globally, an estimated 36.7 million people were living with Human immunodeficiency virus (HIV) in 2016. The majority of people living with HIV are in sub-Saharan Africa. In the era of combined antiretroviral therapy, the life expectancy of people living with HIV (PLWH) has increased [1-3]. With longer life spans, however, PLWH is developing chronic medical conditions [4-6]. The morbidity and mortality associated with HIV infection were due to opportunistic infections. However, in developed countries, opportunistic infections have been replaced by chronic diseases. whereas, in developing countries like Ethiopia both the opportunistic infections and chronic diseases account a high HIV associated mortality and morbidity[7]. One of the most commonly diagnosed chronic diseases is chronic kidney disease (CKD) [8-10]. Chronic kidney disease is defined as kidney damage or reduced kidney function that persists for more than three months $[11,12]$.

Chronic kidney diseases associated with HIV infection has got increased attention in sub-Saharan Africa as a result of the high HIV prevalence and due to the late HIV diagnosis and initiation of HAART. A research finding showed an increasing prevalence of kidney disease in PLWH compared with the general population, being related to increased mortality and morbidity[13-15]. HIV infected patients are five times more likely to develop kidney disease as compared to HIV non infected[16]. A recent systematic review and meta-analysis in sub-Saharan Africa reported a 6.42\% prevalence of CKD among HIV patients in which the majority of them were in stage 3 CKD[17].Chronic kidney disease prevalence is increasing globally and recognized as a global public health problem with major impact on health, health-care costs and productivity $[11,18,19]$. The involved factors related to increased prevalence of kidney disease in PLWH were a direct effect of the virus itself, closely related to the immune status; prolonged use of antiretroviral therapy (tenofovir, indinavir, and others); frequent use of concomitant therapy with nephrotoxic drugs; an increase of comorbidities such as diabetes mellitus, dyslipidemia, and hypertension; high prevalence of coinfection with hepatitis $B$ and $C$ virus compared with general population[20-26].

Ethiopia is among countries where majority of CKD cases were under diagnosed and limited data both among the general population and high-risk groups such as PLWH. Hence, this study was conducted to assess CKD among HIV patients on HARRT in Northwest Ethiopia.

\section{Materials And Methods}

\section{Aim}

The aim of this study was to assess the prevalence of CKD among HIV/AIDS patients and its associated factors.

\section{Study area, design, and population}


A hospital-based cross-sectional study was conducted from February 01, to April 30, 2017 at the University of Gondar Referral Hospital (UOGRH), which is located in the North Gondar zone, $747 \mathrm{~km}$ from the capital city of the country, Addis Ababa. Gondar has an estimated population of more than 206,987 (98,085 males and 108,902 females) based on the 2008 central statistical agency data. at the time of data collection, there were about 13753 HIV patients and 5389 HIV patients on HAART.

Adult HIV/AIDS patients who received HAART in UOGRH were the study population. Those adult HIV/AIDS patients who received HAART for more than 6 months, visited UOGRH during the study period and consented to be involved in the study were included in the study. Whereas, patients who were seriously sick; and unable to give response, diabetic, and hypertension were excluded from the study. In addition, patients with incomplete laboratory and clinical data such as: baseline adherence, baseline drug regimen, HIV/AIDS WHO stage, weight, etc. were excluded from study.

\section{Sample size determination and sampling technique}

Based on single population formula and systematic random sampling technique with the following assumption, $\mathrm{P}=$ population proportion (estimated prevalence) $=0.5$ to yield maximum sample size, precision $d, 0.05$, by assuming $95 \%$ confidence interval $\alpha=0.05$ and $z(1-a / 2)=1.96$ was used for sample size determination. Including $10 \%$ non response rate, the final sample size was 423 . However, a total of 336 HIV patients on HARRT participated in the study (Fig. 1).

During the three-month data collection period, 1320 HIV/AIDS patients on HAART ( $>6$ months) were expected to visit the hospital for follow up. The average number of HIV/AIDS patients per day under follow up was 20 sampling intervals ( $K$ value) was calculated with $1320 / 423=3.12=3$. Thus interviews, chart review and blood and urine specimen collection for chemistry analysis and urine dipstick were conducted at 3 intervals. To determine the first-person, the lottery method was used at 1 st day from the 20 patients who had under follow up. Then each 3rd client was selected for interview, chart review and blood chemistry and urine dipstick test. If the 3rd patient is not fulfilling the inclusion criteria; the next person was taken as a study subject.

\section{Data collection and laboratory methods}

Socio-demographic characteristics and clinical data were collected by trained nurses using a semistructured questionnaire. The patient individual chart was also reviewed for relevant information. Variables included age, gender, residence, education, occupation, viral load, CD4 count, co-infections, base line CD4 + count, regimen type, WHO stage, duration of follow up time, etc.

About 3-5 ml of venous blood was collected aseptically from the patients and serum was separated after the sample clotted and centrifuged at $1000-2000 \mathrm{~g}$ for 10 minutes by trained laboratory technologist. A serum sample was immediately separated from the whole blood and transferred to nunc tube. The serum was kept frozen at $-20^{\circ} \mathrm{C}$ until processed. A serum creatinine level was determined using Mindray BS-200 chemistry analyzer (Shenzhen Mindray Bio-Medical Electronics Co. Ltd, China) and reported in $\mathrm{mg} / \mathrm{dL}$. About $5 \mathrm{ml}$ of urine specimen was collected using clean, dry and leak proof urine cup 
for urine protein level determination. Chemical analysis of urine specimens was performed immediately after sample collection using urine dipsticks test (Multistix ${ }^{\circledR}$ Henry Schein, Inc.https://www.henryschein.com/medical-multistix.aspx). Urine protein level was reported semiquantitatively as negative, or +1 , to +4 . Glomerular filtration rate (GFR) was estimated using CKD-EPI question[27].Chronic kidney disease was defined using eGFR and presence of albuminuria and classified into five stages according to the classification of Kidney Disease Improving Global Outcomes (KDIGO) [28].

\section{Variables' definition}

Chronic kidney disease is defined as abnormalities of kidney structure or function, present for $\geq 3$ months, with implications for health and CKD is classified based on cause, GFR category, and proteinuria category [29].

- Stage 1, persistent proteinuria with eGFR $\geq 90 \mathrm{ml} / \mathrm{min} / 1.73 \mathrm{~m}^{2}$

- Stage 2, persistent proteinuria with eGFR of $60-89.9 \mathrm{ml} / \mathrm{min} / 1.73 \mathrm{~m}^{2}$

- Stage 3, eGFR 30-59.9 ml/min/1.73 $\mathrm{m}^{2}$ with or without proteinuria

- $3 A$ (eGFR $\left.45-59.9 \mathrm{ml} / \mathrm{min} / 1.73 \mathrm{~m}^{2}\right)$

- $3 B\left(\right.$ eGFR $30-44.9 \mathrm{ml} / \mathrm{min} / 1.73 \mathrm{~m}^{2}$ )

- Stage 4, eGFR $15-29.9 \mathrm{ml} / \mathrm{min} / 1.73 \mathrm{~m}^{2}$ with or without proteinuria

- Stage 5, (kidney failure), eGFR< $15 \mathrm{ml} / \mathrm{min} / 1.73 \mathrm{~m}^{2}$ with or without proteinuria.

HAART experienced: taking HAART for more than 6 months which is composed of two NRTIs plus an NNRTI [30].

Underweight, normal weight, overweight and obesity was defined as a $\mathrm{BMI}<18.5 \mathrm{~kg} / \mathrm{m}^{2}, 18.5-$ $24.9 \mathrm{~kg} / \mathrm{m}^{2}, 25-29.9 \mathrm{~kg} / \mathrm{m}^{2}$ and $\geq 30 \mathrm{~kg} / \mathrm{m}^{2}$, respectively [31].

Hypertension: defined as systolic blood pressure $\geq 140 \mathrm{mmHg}$ and/or diastolic blood pressure $\geq$ $90 \mathrm{mmHg}$ or taking medication for blood pressure-lowering [32].

Adherence: adherence was calculated as No of the dose of HAART taken / No of prescribed doses of HAART $\times 100 \%$. Good adherence, $>95 \%$, fair adherence, $85-95 \%$ and poor adherence, $<85 \%$ doses take[33, 34].

\section{Data processing and analysis}

The completeness of the data was checked and entered into SPSS version 20 for analysis. During analysis, descriptive statistics such as percentage, mean and standard deviation were used. Bivariate logistic regression was used to assess the crude association between independent and dependent variables, and with $p$-value $\leq 0.20$ were considered for multivariate logistic regression. Finally, logistic 
regression was used to identify independent predictors of CKD and $p$-value $<0.05$ was considered statistically significant.

\section{Results}

\section{Socio-demographic characteristics}

A total of $336 \mathrm{HIV/AIDS}$ patients who received HAART were enrolled in the study. Of these, 215(64\%) of them were females and $121(36 \%)$ were males. The mean (SD) age of the participants was $39.7( \pm 9.7)$ years, range 18-69 years. One hundred thirty-three (39.6\%) of the study participants were within the age group of 30-39 years. At the time of study almost half of patients, $170(50.6 .4 \%)$ were married and $263(78.3 \%)$ were living in urban areas. Three hundred five $(90.8 \%)$ were followers of orthodox religion (Table 1). 
Table 1

Sociodemographic characteristics of HIV/AIDs patients on HARRT at the University of Gondar Referral Hospital, 2017.

\begin{tabular}{|c|c|c|c|}
\hline Variables & & Frequency & Percent \\
\hline \multirow[t]{4}{*}{ Age } & $18-29$ & 39 & 11.6 \\
\hline & $30-39$ & 133 & 39.6 \\
\hline & $40-49$ & 110 & 32.7 \\
\hline & $>=50$ & 54 & 16.1 \\
\hline \multirow[t]{4}{*}{ Marital status } & Single & 72 & 21.4 \\
\hline & Married & 170 & 50.6 \\
\hline & Divorced & 69 & 20.5 \\
\hline & Widowed & 25 & 7.4 \\
\hline \multirow[t]{2}{*}{ Gender } & Female & 215 & 64 \\
\hline & Male & 121 & 36 \\
\hline \multirow[t]{2}{*}{ Resident } & Urban & 263 & 78.3 \\
\hline & Rural & 73 & 21.7 \\
\hline \multirow[t]{8}{*}{ Occupation } & Farmer & 43 & 12.8 \\
\hline & Merchant & 44 & 13.1 \\
\hline & Student & 13 & 3.9 \\
\hline & government employ & 33 & 9.8 \\
\hline & daily laborer & 52 & 15.5 \\
\hline & house life & 81 & 24.1 \\
\hline & Private employ & 53 & 15.8 \\
\hline & Other & 17 & 5.1 \\
\hline \multirow[t]{4}{*}{ Educational status } & Illiterate & 99 & 29.5 \\
\hline & primary school & 85 & 25.3 \\
\hline & secondary school & 119 & 35.4 \\
\hline & Tertiary & 33 & 9.8 \\
\hline \multirow[t]{2}{*}{ Religion } & Orthodox & 305 & 90.8 \\
\hline & Muslim & 24 & 7.1 \\
\hline
\end{tabular}




\begin{tabular}{|llll|}
\hline Variables & & Frequency & Percent \\
\hline & Protestant & 7 & 2.1 \\
\cline { 2 - 4 } & Total & 336 & 100 \\
\hline
\end{tabular}

\section{Clinical Characteristics of HIV/AIDS patients}

The study patients were on ART with a minimum of 1 up to 12 years with an average time of $7.5( \pm 3)$ years. Before ART initiation majority of patients had WHO clinical stage II and III, 251 (74.7\%), CD $4+$ T cell count $<200$ cells $/ \mathrm{mm}^{3}, 221$ (65.8\%), good adherence 321(95.5\%) and on AZT + 3TC + NVP 121 (36\%) regimen followed by TDF + 3TC + EFV 62 (18.5\%).

Majority of study participants, 326 (97\%) were on WHO clinical stage I, $28(8.3 \%)$ had CD4 + T count $<200$ cells $/ \mathrm{mm}^{3}, 333(99.1 \%)$ had good adherence and $126(37.5 \%)$ switched to first-line or second-line regimen, 11 (3.3\%). The most common reason for switching was toxicity, $93(27.7 \%)$ followed by clinical failure, 17 (5.1\%). The common opportunistic infections observed during their ART follow up was TB, 77 (22.9\%). The mean plasma viral load level was $6023.46 \mathrm{copies} / \mathrm{ml}$ (range $0-245754.00 \mathrm{copies} / \mathrm{ml}$ ). Among all the study participants, 27 (8.0\%), 16 (4.8\%), 6 (1.8\%) and 5 (1.5\%) of patients during follow-up were stage I, stage II, stage III and stage $\mathrm{V}$ respectively (Table 2 ). 
Table 2

Clinical characteristics of HIV/AIDs patients on HARRT at the University of Gondar Referral Hospital, 2017.

\begin{tabular}{|c|c|c|c|}
\hline \multicolumn{2}{|l|}{ Variables } & \multirow{2}{*}{$\begin{array}{l}\text { Frequency } \\
110\end{array}$} & \multirow{2}{*}{$\begin{array}{l}\text { Percent } \\
32.7\end{array}$} \\
\hline Duration on ART in year & $<=6$ & & \\
\hline & $>6$ & 226 & 67.3 \\
\hline Mean ART duration in year & 7.5 year $(+3)$ & & \\
\hline \multirow[t]{4}{*}{ Base line WHO stage } & WHO stage I & 40 & 11.9 \\
\hline & WHO stage II & 72 & 21.4 \\
\hline & WHO stage III & 179 & 53.3 \\
\hline & WHO stage IV & 45 & 13.4 \\
\hline \multirow[t]{3}{*}{ WHO stage during data collection } & WHO stage I & 7 & 2.1 \\
\hline & WHO stage II & 326 & 97 \\
\hline & WHO stage III & 3 & 9 \\
\hline \multirow[t]{7}{*}{ Type of Opportunistic infection } & No & 238 & 70.8 \\
\hline & Protozoa & 4 & 1.2 \\
\hline & Helminths & 8 & 2.4 \\
\hline & Hepatitis viruses & 2 & 0.6 \\
\hline & fungal infections & 1 & 0.3 \\
\hline & TB & 77 & 22.9 \\
\hline & Mixed & 6 & 1.8 \\
\hline \multirow[t]{7}{*}{ Initial regimen } & $\mathrm{D} 4 \mathrm{~T}+3 \mathrm{TC}+\mathrm{NVP}$ & 66 & 19.6 \\
\hline & $\mathrm{D} 4 \mathrm{~T}+3 \mathrm{TC}+\mathrm{EFV}$ & 28 & 8.3 \\
\hline & $A Z T+3 T C+N V P$ & 121 & 36.0 \\
\hline & $A Z T+3 T C+E F V$ & 25 & 7.4 \\
\hline & $\mathrm{TDF}+3 \mathrm{TC}+\mathrm{EFV}$ & 62 & 18.5 \\
\hline & $T D F+3 T C+N V P$ & 25 & 7.4 \\
\hline & $\mathrm{D} 4 \mathrm{~T}+3 \mathrm{TC}+\mathrm{NVP}$ & 5 & 1.5 \\
\hline
\end{tabular}

*ADH = adherence, $A R V=$ Antiretroviral, $D 4 T=$ StavudineTDF $=$ TenofovirDisoproxilFumarate, $A Z T /$ 3TC = Zidovudine $/$ Lamivudine, EFV = Efavirenze, NVP = NevirapineABC = abacavir, ddl = didanosine, $\mathrm{LPV} / \mathrm{R}=$ lopinavir/ritonavir, 


\begin{tabular}{|c|c|c|c|}
\hline \multicolumn{2}{|l|}{ Variables } & \multirow{2}{*}{$\begin{array}{l}\text { Frequency } \\
4\end{array}$} & \multirow{2}{*}{$\begin{array}{l}\text { Percent } \\
1.2\end{array}$} \\
\hline & Pediatric 4C $(A Z T+3 T C+N V P)$ & & \\
\hline \multirow[t]{3}{*}{ Switching } & No & 199 & 59.2 \\
\hline & Yes & 137 & 40.8 \\
\hline & Total & 336 & 100.0 \\
\hline \multirow[t]{2}{*}{ Switching } & To 1st line drug & 126 & 37.5 \\
\hline & To 2nd line drug & 11 & 3.3 \\
\hline \multirow[t]{6}{*}{ Second regimen } & $A Z T+3 T C+N V P 1 C$ & 52 & 15.5 \\
\hline & $A Z T+3 T C+E F V 1 d$ & 22 & 6.5 \\
\hline & $T D F+3 T C+N V P 1 e$ & 21 & 6.3 \\
\hline & $T D F+3 T C+E F V 1 f$ & 31 & 9.2 \\
\hline & $A B C+d d l+L P V / R 2 a$ & 10 & 3.0 \\
\hline & $\mathrm{TDF}+\mathrm{ddl}+\mathrm{IPV} / \mathrm{R} 2 \mathrm{c}$ & 1 & 0.3 \\
\hline \multirow[t]{5}{*}{ Reason of switching drug } & Toxicity & 93 & 27.7 \\
\hline & Pregnancy & 5 & 1.5 \\
\hline & TB & 16 & 4.8 \\
\hline & Clinical failure & 17 & 5.1 \\
\hline & Age & 6 & 1.8 \\
\hline \multirow[t]{3}{*}{ ARV drug ADH at base line } & Good & 321 & 95.5 \\
\hline & Fair & 1 & 0.3 \\
\hline & Poor & 14 & 4.2 \\
\hline \multirow[t]{2}{*}{ ARV drug ADH During data collection } & Good & 333 & 99.1 \\
\hline & Poor & 3 & 0.9 \\
\hline \multirow[t]{4}{*}{ Base line CD 4 count } & $<=199$ & 221 & 65.8 \\
\hline & $200-349$ & 95 & 28.3 \\
\hline & $350-499$ & 16 & 4.8 \\
\hline & $>=500$ & 4 & 1.2 \\
\hline $\begin{array}{l}\text { *ADH = adherence, } A R V=\text { Antiretroviral } \\
3 T C=\text { Zidovudine } / \text { Lamivudine, EFV }= \\
\text { LPV } / \mathrm{R}=\text { lopinavir/ritonavir, }\end{array}$ & $\begin{array}{l}1 \mathrm{HT}=\text { StavudineTDF = TenofovirDi } \\
\text { irenze, NVP = NevirapineABC = a }\end{array}$ & $\begin{array}{l}\text { oxilFumarat } \\
\text { avir, ddl = did }\end{array}$ & $\begin{array}{l}\text { AZT/ } \\
\text { losine, }\end{array}$ \\
\hline
\end{tabular}




\begin{tabular}{|c|c|c|c|}
\hline \multicolumn{2}{|l|}{ Variables } & \multirow{2}{*}{$\begin{array}{l}\text { Frequency } \\
28\end{array}$} & \multirow{2}{*}{$\begin{array}{l}\text { Percent } \\
8.3\end{array}$} \\
\hline CD4 count during data collection & $<=199$ & & \\
\hline & $200-349$ & 89 & 26.5 \\
\hline & $350-499$ & 92 & 27.4 \\
\hline & $>=500$ & 127 & 37.8 \\
\hline \multirow[t]{5}{*}{ Viral load } & Undetected & 178 & 53.0 \\
\hline & $0-19$ & 66 & 19.6 \\
\hline & $20-999$ & 42 & 12.5 \\
\hline & $>=1000$ & 50 & 14.9 \\
\hline & Total & 336 & 100 \\
\hline \multirow[t]{4}{*}{ Component of immunological failure } & CD4 falling more than $50 \%$ & 22 & 6.5 \\
\hline & CD4 falling below Baseline & 12 & 3.6 \\
\hline & CD4 persistently below 100 & 3 & 9 \\
\hline & Total & 37 & 11.0 \\
\hline \multicolumn{4}{|c|}{$\begin{array}{l}\text { *ADH = adherence, } A R V=\text { Antiretroviral, } \mathrm{D} 4 \mathrm{~T}=\mathrm{StavudineTDF}=\text { TenofovirDisoproxilFumarate, } \mathrm{AZT} / \\
\text { 3TC }=\text { Zidovudine } / \text { Lamivudine, } \mathrm{EFV}=\mathrm{Efavirenze}, \mathrm{NVP}=\text { NevirapineABC = abacavir, ddl = didanosine, } \\
\mathrm{LPV} / \mathrm{R}=\text { lopinavir/ritonavir, }\end{array}$} \\
\hline
\end{tabular}

Using CKD-EPI GFR estimator, about 27 (8.0\%) of the participants had stage 1 and 16 (4.8\%) stage 2 CKD. Whereas, only 11 (3.3\%) of them developed chronic renal failure (stage 3a-5). The overall prevalence of CKD defined as protein urea of $\geq+1$ and/or GFR $<60$ was $16.1 \%$ (Table 3 ). 
Table 3

Stages of kidney functions using the CKD-EPI estimator among HIV/AIDs patients on HARRT at the University of Gondar Referral Hospital, 2017.

\begin{tabular}{|lll|}
\hline Stages of CKD & GFR estimation & $\begin{array}{l}\text { CKD } \\
\text { N }(\%)\end{array}$ \\
\hline 1 & $\geq 90$, with proteinuria $(\geq+1)$ & $27(8.0)$ \\
\hline 2 & $60-89$, with proteinuria $(\geq+1)$ & $16(4.8)$ \\
\hline $3 a$ & $45-59.9$, with or without proteinuria $(\geq+1)$ & $6(1.8)$ \\
\hline $3 b$ & $30-44.9$, with or without proteinuria $(\geq+1)$ & $0(0)$ \\
\hline 4 & $15-29.9$, with or without proteinuria $(\geq+1)$ & $0(0)$ \\
\hline 5 & $<15$, with or without proteinuria $(\geq+1)$ & $5(1.5)$ \\
\hline & Overall CKD & $54(16.1 \%)$ \\
\hline
\end{tabular}

\section{Associated factors of Chronic kidney disease}

In bivariate logistic regression analysis associated factors gender, occupation, duration on ART; viral load was found to be a $p$-value of $<0.2$. When it was analyzed with multivariate logistic regression analysis being male, occupation (merchant) and $V L \geq 100$ copies $/ \mathrm{mm}^{3}$ were significant factors $(p<0.05)$ for chronic kidney disease. Male patients on follow up (AOR $=2.05(1.03-4.09),=0.04)$, merchant patients(AOR = 2.91(1.00-8.48), $\mathrm{P}=0.049)$ and patients who have had $\mathrm{VL} \geq 1000$ (AOR = 3.1 (1.38-7.00), $\mathrm{P}$ $<0.01$ ) were 2, 2.9 and 3 times more likely to have chronic kidney disease compared with their comparison group females, housewife and viral load $<20$ copies $/ \mathrm{mm}^{3}$ respectively (Table 4 ). 
Table 4

Bivariate and multivariate analysis of chronic kidney disease associated factors among HIV/AIDs patients on HARRT at the University of Gondar Referral Hospital 2017.

\begin{tabular}{|c|c|c|c|c|c|c|c|}
\hline \multirow[t]{2}{*}{ Variables } & & \multicolumn{2}{|l|}{ CKD } & \multirow{2}{*}{$\begin{array}{l}\text { COR } \\
(95 \% \mathrm{Cl})\end{array}$} & \multirow{2}{*}{$\begin{array}{l}\mathrm{p}- \\
\text { value }\end{array}$} & \multirow[t]{2}{*}{$\mathrm{AOR}(95 \% \mathrm{Cl})$} & \multirow{2}{*}{$\begin{array}{l}\mathrm{p}- \\
\text { value }\end{array}$} \\
\hline & & Yes & No & & & & \\
\hline \multirow[t]{2}{*}{ Gender } & Female & 183 & 26 & & & Ref & \\
\hline & Male & 93 & 28 & $\begin{array}{l}2.19(1.22- \\
3.94)\end{array}$ & 0.009 & $\begin{array}{l}2.05(1.03- \\
4.09)\end{array}$ & $0.04^{\star}$ \\
\hline \multirow[t]{6}{*}{ Occupation } & Farmer & 38 & 4 & $\begin{array}{l}0.96(0.27- \\
3.40)\end{array}$ & 0.95 & $\begin{array}{l}0.63(0.16- \\
2.51)\end{array}$ & 0.51 \\
\hline & Merchant & 32 & 13 & $\begin{array}{l}3.71(1.40- \\
9.82)\end{array}$ & 0.008 & $\begin{array}{l}2.91(1.00- \\
8.48)\end{array}$ & $0.049 *$ \\
\hline & Student & 10 & 3 & $\begin{array}{l}2.74(0.62- \\
12.05)\end{array}$ & 0.18 & $\begin{array}{l}1.13(0.22- \\
5.90)\end{array}$ & 0.89 \\
\hline & $\begin{array}{l}\text { Governmental } \\
\text { employee }\end{array}$ & 72 & 13 & $\begin{array}{l}1.165(0.64- \\
4.21)\end{array}$ & 0.30 & $\begin{array}{l}1.18(0.42- \\
3.30)\end{array}$ & 0.76 \\
\hline & daily laborer & 57 & 13 & $\begin{array}{l}2.08(0.81- \\
5.36)\end{array}$ & 0.13 & $\begin{array}{l}1.52(0.55- \\
4.16)\end{array}$ & 0.42 \\
\hline & household wife & 73 & 8 & Ref & Ref & Ref & \\
\hline \multirow[t]{2}{*}{$\begin{array}{l}\text { Duration on } \\
\text { ART in year }\end{array}$} & $<=6$ & 196 & 30 & $\begin{array}{l}1.82(1.01- \\
3.30)\end{array}$ & 0.05 & $\begin{array}{l}1.06(0.21- \\
5.37)\end{array}$ & 0.95 \\
\hline & $>6$ & 86 & 24 & Ref & & Ref & \\
\hline \multirow{4}{*}{$\begin{array}{l}\text { Viral load } \\
\text { category }\end{array}$} & Undetectable & 156 & 22 & Ref & & Ref & \\
\hline & $<20$ & 56 & 10 & $\begin{array}{l}1.27(0.57- \\
2.84)\end{array}$ & 0.57 & $\begin{array}{l}1.13(0.49- \\
2.61)\end{array}$ & 0.78 \\
\hline & $20-999$ & 35 & 7 & $\begin{array}{l}1.42(0.56- \\
3.58)\end{array}$ & 0.46 & $\begin{array}{l}1.30(0.48- \\
3.48)\end{array}$ & 0.60 \\
\hline & $>1000$ & 35 & 15 & $\begin{array}{l}3.04(1.43- \\
6.45)\end{array}$ & 0.004 & $\begin{array}{l}3.10(1.38- \\
7.00)\end{array}$ & $0.01 *$ \\
\hline
\end{tabular}

Note

* Has significant association

*COR $=$ crude odds ratio, $\mathrm{AOR}=$ adjusted odds ratio Ref $=$ reference $\mathrm{Cl}=$ confidence interval $\mathrm{p}=$ significant value, 
The current study assessed the prevalence and associated factors of CKD in HIV patients on HAART using the commonest estimator of kidney function method CKD-EPI. The finding of this study revealed a high frequency of CKD and the related risk factors mostly being male, occupation merchant and patients with $\mathrm{VL} \geq 1000$. The prevalence of CKD, $16.1 \%$ was consistency with the previous study conducted in Ethiopia, 12.1\% [33], Ghana, 14.5\% [35], Nigeria, 15.3\%[36] and Tokyo, 13\%[37]. However, the result was higher as compared to a study conducted in Uganda, 6\% [38], Nigeria, 6.9\% [39], Brazil, 8.4\%[40], Southwest Ethiopia, 7.6\% [41], Tanzania, 1.1\% [42], and Lesotho, 5.5\% [43]. The observed differences could be due to study design, study area and their lifestyle, and the method used to estimate GFR.

This study showed, male gender was significantly associated with renal impairment and was 2.05 times more likely to have chronic kidney disease as compared with its comparison group female. The finding agrees with the study findings conducted in France [44], and South Africa[45]. The lower prevalence of CKD in females may be due to the possible protective role promoted by estrogens hormone or due to the absence of the profibrotic effects caused by testosterone [46, 47].This study also showed that being occupation merchant was independently and significantly associated with chronic kidney disease. Merchant patients were 2.9 times high risk than the comparative group housewife. In the current study more than half, (51\%) of the occupation, merchant participant group were male. Since the higher prevalence of CKD on male than females might be due to the possible CKD protective role promoted by estrogens hormone in females or due to the absence of the profibrotic effects caused by testosterone hormone in females compared to males[46, 47].

In the current study patients who have had VL $\geq 1000$ were three times more likely to have chronic kidney disease compared with its comparison group patents who have had viral load $<20$ copies $/ \mathrm{mm}^{3}$ respectively. This result is agreed with the study conducted in America [5, 48] and Thailand [49]. High viral replication increased renal damage may be occurred due to destruction of kidney cells and the nephrons. Viral suppression would improve renal function $[22,50,51]$.

\section{Conclusion}

The prevalence of CKD in our study based on glomerular filtration rate using CKD-EPI method was high(16.1\%). Male gender, merchant, and VL $\geq 1000$ were associated factors of chronic kidney diseases CKD among HIV patients on HARRT. Hence, HIV patients on HARRT should be regularly screened for early diagnosis and management of CKD. Those patients with high viral load and male patients should be closely followed.

\section{List Of Abbreviations}

ABC Abacavir

AIDS Acquired Immune Deficiency Syndromes

ART Antiretroviral Therapy

Page $14 / 21$ 
ARV Anti-retroviral Virus

AZT/ 3TC Zidovudine/ Lamivudine

CKD Chronic Kidney disease

DDI Didanosine

EFV Efavirenze

ESRD end-stage renal disease

eGFR estimated glomerular filtration rate

GFR glomerular filtration rate

HAART Highly Active Antiretroviral Therapy

HIV Human Immune Deficiency Virus

LPV/R Lopinavir/ritonavir

NNRT Non-Nucleoside Rivers Transcriptase

NRT Nucleoside Rivers Transcriptase

NVP Nevirapine

Ol Opportunistic Infections

PLHIV People Living with Human Immune Deficiency Virus

Pls Proteinase Inhibitors

TDF TenofovirDisoproxilFumarate

VL Viral Load

\section{Declarations}

\section{Ethics approval and consent to participate}

Ethical clearance was acquired from the Research and Ethical Review Committee of School of Biomedical and Laboratory Sciences, College of Medicine and Health Sciences, University of Gondar. The permission letter was taken from the clinical director of the University of Gondar specialized referral hospital and head of the ART clinic. The privacy of personal information was protected and kept confidential. For the purpose of the study, codes were used instead of any personal identifiers. Data were 
collected after full written consent had been obtained from each participant. Patients with abnormal test results were linked to consulting physicians for further diagnosis and treatment accordingly.

Consent for publication

Not applicable

\section{Data Availability}

The data used to support the findings of this study are available from the corresponding author upon request

\section{Competing interests}

We declare that we do not have any conflict of interests.

\section{Authors' contribution}

GAM: study design, data collection, analysis and interpretation, and manuscript write-up. DDA and WNA: data analysis and interpretation, study design and supervision. All authors have read and approved the final manuscript.

\section{Funding}

University of Gondar

\section{Acknowledgments}

We would like to express our appreciation to the study participants for their willingness to give samples and required information and staff of the ART clinic of the University of Gondar Referral Teaching Hospital for their support during data collection.

\section{References}

1. Althoff KN, McGinnis KA, Wyatt CM, Freiberg MS, Gilbert C, Oursler KK, Rimland D, RodriguezBarradas MC, Dubrow R, Park LS. Comparison of risk and age at diagnosis of myocardial infarction, end-stage renal disease, and non-AIDS-defining cancer in HIV-infected versus uninfected adults. Clin Infect Dis. 2015;60(4):627-38.

2. Nakagawa F, Lodwick RK, Smith CJ, Smith R, Cambiano V, Lundgren JD, Delpech V, Phillips AN.

Projected life expectancy of people with HIV according to timing of diagnosis. Aids. 2012;26(3):33543.

3. Samji H, Cescon A, Hogg RS, Modur SP, Althoff KN, Buchacz K, Burchell AN, Cohen M, Gebo KA, Gill MJ. Closing the gap: increases in life expectancy among treated HIV-positive individuals in the United States and Canada. PloS one 2013, 8(12). 
4. Cailhol J, Nkurunziza B, Izzedine H, Nindagiye E, Munyana L, Baramperanye E, Nzorijana J, Sakubu D, Niyongabo T, Bouchaud O. Prevalence of chronic kidney disease among people living with HIV/AIDS in Burundi: a cross-sectional study. BMC Nephrol. 2011;12(1):40.

5. Calza L, Vanino E, Magistrelli E, Salvadori C, Cascavilla A, Colangeli V, Di Bari MA, Manfredi R, Viale P. Prevalence of renal disease within an urban HIV-infected cohort in northern Italy. Clin Exp Nephrol. 2014;18(1):104-12.

6. Campbell L, Ibrahim F, Fisher M, Holt S, Hendry B, Post F. Spectrum of chronic kidney disease in HIVinfected patients. HIV medicine. 2009;10(6):329-36.

7. Wools-Kaloustian KK, gupta SK. Will there be an epidemic of HIV-related chronic kidney disease in sub-Saharan Africa? Too soon to tell. Kidney Int. 2008;74(7):845-7.

8. Bonjoch A, Juega J, Puig J, Pérez-Alvarez N, Aiestarán A, Echeverria P, Pérez V, Clotet B, Romero R, Bonet J. High prevalence of signs of renal damage despite normal renal function in a cohort of HIVinfected patients: evaluation of associated factors. AIDS Patient Care STDs. 2014;28(10):524-9.

9. Naicker S, Rahmania S, Kopp JB. HIV and chronic kidney disease. Clin Nephrol. 2015;83(Suppl 1):32.

10. Kopple JD. National kidney foundation K/DOQI clinical practice guidelines for nutrition in chronic renal failure. American journal of kidney diseases. 2001;37(1):66-70.

11. Coresh J, Astor BC, Greene T, Eknoyan G, Levey AS. Prevalence of chronic kidney disease and decreased kidney function in the adult US population: Third National Health and Nutrition Examination Survey. American journal of kidney diseases. 2003;41(1):1-12.

12. Szczech LA, Hoover DR, Feldman JG, Cohen MH, Gange SJ, Goozé L, Rubin NR, Young MA, Cai X, Shi Q. Association between renal disease and outcomes among HIV-infected women receiving or not receiving antiretroviral therapy. Clinical infectious diseases. 2004;39(8):1199-206.

13. Szczech LA, Gupta SK, Habash R, Guasch A, Kalayjian R, Appel R, Fields TA, Svetkey LP, Flanagan $\mathrm{KH}, \mathrm{Klotman} \mathrm{PE}$. The clinical epidemiology and course of the spectrum of renal diseases associated with HIV infection. Kidney international. 2004;66(3):1145-52.

14. Wyatt CM, Arons RR, Klotman PE, Klotman ME. Acute renal failure in hospitalized patients with HIV: risk factors and impact on in-hospital mortality. Aids. 2006;20(4):561-5.

15. Röling J, Schmid H, Fischereder M, Draenert R, Goebel F. HIV-associated renal diseases and highly active antiretroviral therapy-induced nephropathy. Clin Infect Dis. 2006;42(10):1488-95.

16. Islam FM, Wn J, Jansson J, Wilson DP. Relative risk of renal disease among people living with HIV: A systematic review and meta-analysis. BMC Public Health. 2012;12:234.

17. Baynes HW, Negash M, Geremew D, Getaneh Z. Chronic Kidney Disease among Human Immunodeficiency Virus Positive Patients on Antiretroviral Therapy in Sub-Saharan Africa: A Systematic Review and Meta-analysis. Saudi Journal of Kidney Diseases Transplantation. 2019;30(6):1190-200.

18. Gilbertson DT, Liu J, Xue JL, Louis TA, Solid CA, Ebben JP, Collins AJ. Projecting the number of patients with end-stage renal disease in the United States to the year 2015. J Am Soc Nephrol. 2005;16(12):3736-41. 
19. Levey A, Atkins R, Coresh J, Cohen E, Collins A, Eckardt K-U, Nahas M, Jaber B, Jadoul M, Levin A. Chronic kidney disease as a global public health problem: approaches and initiatives-a position statement from Kidney Disease Improving Global Outcomes. Kidney international. 2007;72(3):24759.

20. Gupta SK, Eustace JA, Winston JA, Boydstun II, Ahuja TS, Rodriguez RA, Tashima KT, Roland M, Franceschini N, Palella FJ. Guidelines for the management of chronic kidney disease in HIV-infected patients: recommendations of the HIV Medicine Association of the Infectious Diseases Society of America. Clin Infect Dis. 2005;40(11):1559-85.

21. Sida PdedGdEdSydPNse. Diagnóstico, tratamiento y prevención de las alteraciones renales en pacientes con infección por el virus de la inmunodeficiencia humana. Recomendaciones del Grupo de Estudio del Sida/Plan Nacional sobre el Sida. Enfermedades Infecciosas y Microbiología Clínica. 2010;28(8):520. e521-520. e522.

22. Fernando SK, Finkelstein FO, Moore BA, Weissman S. Prevalence of chronic kidney disease in an urban HIV infected population. Am J Med Sci. 2008;335(2):89-94.

23. De Silva TI, Post FA, Griffin MD, Dockrell DH: HIV-1 infection and the kidney: an evolving challenge in HIV medicine. In: Mayo Clinic Proceedings: 2007: Elsevier; 2007: 1103-1116.

24. Fulop T, Olivier J, Meador R, Hall J, Islam N, Mena L, Henderson H, Schmidt D. Screening for chronic kidney disease in the ambulatory HIV population. Clin Nephrol. 2010;73(3):190-6.

25. Di AB, Rosso R, Vitale F, Cardinale F, Sormani M, Secondo G, Di LS, Viscoli C. Risk factors for chronic kidney disease among human immunodeficiency virus-infected patients: A European case control study. Clin Nephrol. 2011;75(6):518-23.

26. Flandre P, Pugliese P, Cuzin L, Bagnis Cl, Tack I, Cabié A, Poizot-Martin I, Katlama C, Brunet-François C, Yazdanpanah Y. Risk factors of chronic kidney disease in HIV-infected patients. Clin J Am Soc Nephrol. 2011;6(7):1700-7.

27. Crum NF, Riffenburgh RH, Wegner S, Agan BK, Tasker SA, Spooner KM, Armstrong AW, Fraser S, Wallace MR, Consortium TAC. Comparisons of causes of death and mortality rates among HIVinfected persons: analysis of the pre-, early, and late HAART (highly active antiretroviral therapy) eras. JAIDS Journal of Acquired Immune Deficiency Syndromes. 2006;41(2):194-200.

28. Joint U. Programme on HIV/AIDS. Prevention gap report. Geneva: Joint United Nations Programme on HIV. AIDS 2016, 3.

29. Andrassy KM: Comments on 'KDIGO 2012 clinical practice guideline for the evaluation and management of chronic kidney disease'. Kidney international 2013, 84(3):622-623.

30. Denue BA, Muazu PJ, Gashau W, Nkami D, Ajayi NA. Effects of highly active antiretroviral therapy (HAART) on blood pressure changes and its associated factors in HAART naive HIV-infected patients in north eastern Nigeria. Archives of Applied Science Research. 2012;4(3):1447-52.

31. Seidell JC, Flegal KM. Assessing obesity: classification and epidemiology. British medical bulletin. $1997 ; 53(2): 238-52$. 
32. Chalmers J, MacMahon S, Mancia G, Whitworth J, Beilin L, Hansson L, Neal B, Rodgers A, Ni CM, Clark T. 1999 World Health Organization-International Society of Hypertension Guidelines for the management of hypertension. Guidelines sub-committee of the World Health Organization. Clinical and experimental hypertension (New York, NY: 1993) 1999, 21(5-6):1009-1060.

33. Kahsu G, Birhan W, Addis Z, Dagnew M, Abera B. Renal Function Impairment and Associated Risk Factors among Human Immunodeficiency Virus Positive Individuals at Flege Hiwot Referral Hospital, Northwest Ethiopia. Journal of Interdisciplinary Histopathology. 2013;1(5):252-60.

34. Baynes HW, Tegene B, Gebremichael M, Birhane G, Kedir W, Biadgo B. Assessment of the effect of antiretroviral therapy on renal and liver functions among HIV-infected patients: a retrospective study. HIV/AIDS (Auckland NZ). 2017;9:1.

35. Owiredu W, Quaye L, Amidu N, Addai-Mensah O. Renal insufficiency in Ghanaian HIV infected patients: need for dose adjustment. Afr Health Sci. 2013;13(1):101-11.

36. Okpa HO, Bisong EM, Enang OE, Effa EE, Monjok E, Essien EJ: Predictors of chronic kidney disease among HIV-infected patients on highly active antiretroviral therapy at the University of Calabar Teaching Hospital, Calabar, South-South Nigeria. HIV/AIDS (Auckland, NZ) 2019, 11:61.

37. Nishijima T, Kawasaki Y, Mutoh Y, Tomonari K, Tsukada K, Kikuchi Y, Gatanaga H, Oka S. Prevalence and factors associated with chronic kidney disease and end-stage renal disease in HIV-1-infected Asian patients in Tokyo. Scientific reports. 2017;7(1):1-8.

38. Peters PJ, Moore DM, Mermin J, Brooks JT, Downing R, Were W, Kigozi A, Buchacz K, Weidle PJ. Antiretroviral therapy improves renal function among HIV-infected Ugandans. Kidney international. 2008;74(7):925-9.

39. Yusuf R, Aliyu I, Anaja P, Muktar H. Prevalence of chronic kidney disease (CKD) in HIV-infected patients in Zaria, Nigeria. Nig Journ Pharm Sci. 2011;10(1):107-11.

40. Menezes AM, Torelly J Jr, Real L, Bay M, Poeta J, Sprinz E. Prevalence and risk factors associated to chronic kidney disease in HIV-infected patients on HAART and undetectable viral load in Brazil. PloS one 2011, 6(10).

41. Mekuria Y, Yilma D, Mekonnen Z, Kassa T, Gedefaw L. Renal Function Impairment and Associated Factors among HAART Naïve and Experienced Adult HIV Positive Individuals in Southwest Ethiopia: A Comparative Cross Sectional Study. PloS one 2016, 11(8).

42. Mpondo BC, Kalluvya SE, Peck RN, Kabangila R, Kidenya BR, Ephraim L, Fitzgerald DW, Downs JA. Impact of antiretroviral therapy on renal function among HIV-infected Tanzanian adults: a retrospective cohort study. PLoS One 2014, 9(2).

43. Bygrave H, Kranzer K, Hilderbrand K, Jouquet G, Goemaere E, Vlahakis N, Trivino L, Makakole L, Ford $\mathrm{N}$. Renal safety of a tenofovir-containing first line regimen: experience from an antiretroviral cohort in rural Lesotho. PLoS One 2011, 6(3).

44. Déti EK, Thiébaut R, Bonnet F, Lawson-Ayayi S, Dupon M, Neau D, Pellegrin J-L, Malvy D, Tchamgoué $\mathrm{S}, \mathrm{Dabis} \mathrm{F}$. Prevalence and factors associated with renal impairment in HIV-infected patients, ANRS C03 Aquitaine Cohort, France. HIV medicine. 2010;11(5):308-17. 
45. Crum-Cianflone N, Ganesan A, Teneza-Mora N, Riddle M, Medina S, Barahona I, Brodine S. Prevalence and factors associated with renal dysfunction among HIV-infected patients. AIDS Patient Care STDs. 2010;24(6):353-60.

46. Silbiger SR, Neugarten J. The impact of gender on the progression of chronic renal disease. American journal of kidney diseases. 1995;25(4):515-33.

47. Neugarten J, Acharya A, Silbiger SR. Effect of gender on the progression of nondiabetic renal disease: a meta-analysis. J Am Soc Nephrol. 2000;11(2):319-29.

48. McMahon BA, Hanouneh M, Chedid A, Fine DM, Chen TK, Foy M, Lucas GM, Estrella MM, Atta MG. Association of HIV Suppression With Kidney Disease Progression Among HIV-Positive African Americans With Biopsy-Proven Classic FSGS. JAIDS Journal of Acquired Immune Deficiency Syndromes. 2018;79(5):639-43.

49. Pongpirul W, Pongpirul K, Ananworanich J, Klinbuayaem V, Avihingsanon A, Prasithsirikul W. Chronic kidney disease incidence and survival of Thai HIV-infected patients. Aids. 2018;32(3):393-8.

50. Park J, Zuniga JA. Chronic kidney disease in persons living with HIV: a systematic review. J Assoc Nurses AIDS Care. 2018;29(5):655-66.

51. Wyatt CM, Morgello S, Katz-Malamed R, Wei C, Klotman ME, Klotman PE, D'Agati VD. The spectrum of kidney disease in patients with AIDS in the era of antiretroviral therapy. Kidney international. 2009;75(4):428-34.

\section{Figures}


Total HIV/AIDS patients at UOGRH ART center $(\mathrm{N}=13753)$

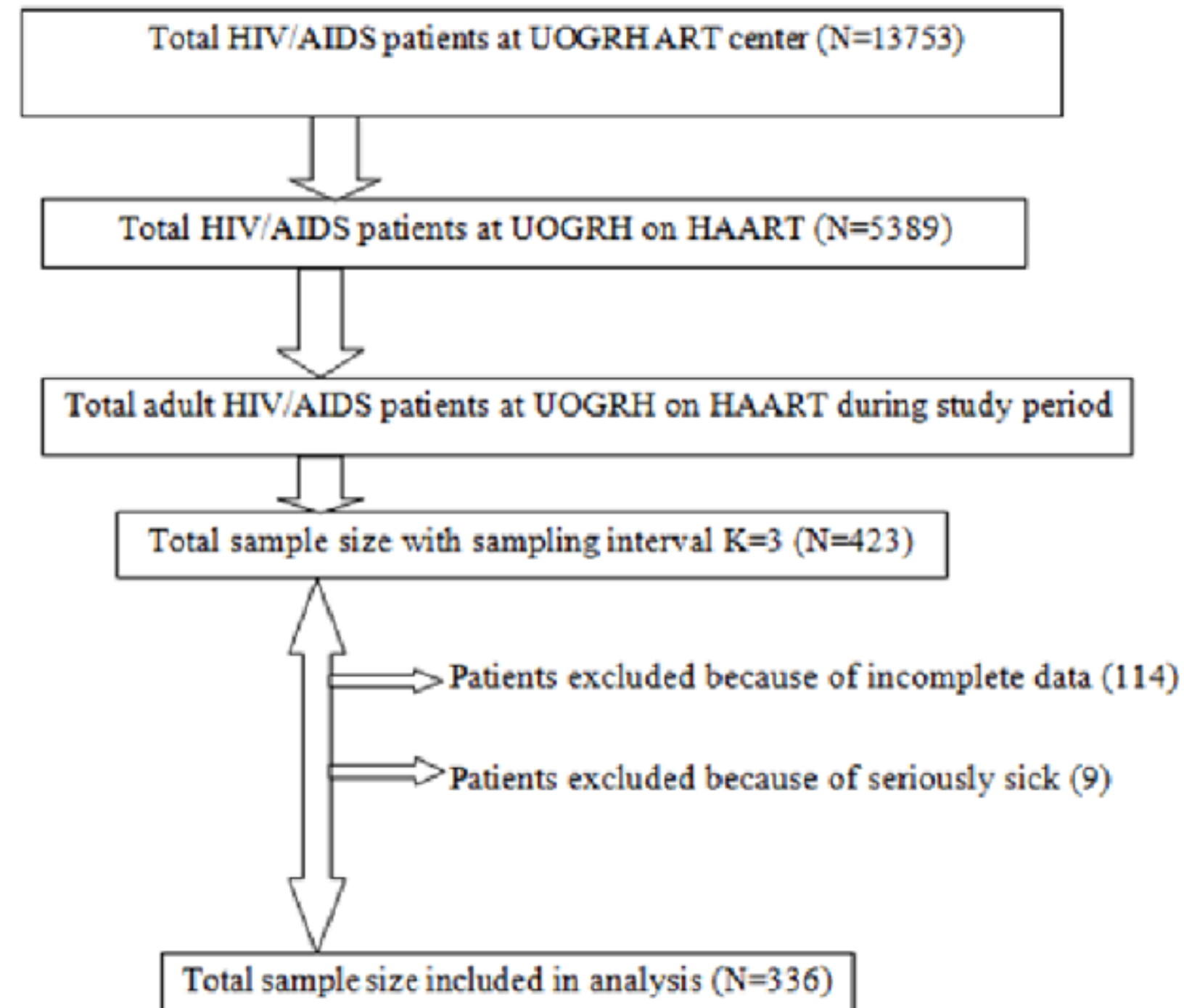

Figure 1

Schematic representation of the sampling procedure adult HIV/AIDS patients on HARRT at University of Gondar Referral Hospital, from February to April 2017. 